\title{
The Impact of Physicochemical Parameters and Heavy Metals on the Biodiversity of Benthic Macrofauna in the Inaouene Wadi (Taza, North East Morocco)
}

\author{
Rezouki Sanae ${ }^{1 *}$, Allali Aimad', Berady Karim ', Habchaoui Jamaa', \\ Eloutassi Noureddine ${ }^{2}$, Fadli Mohamed ${ }^{1}$ \\ 1 Laboratory of Plant, Animal and Agro-industry Productions, Faculty of Sciences, University of Ibn Tofail, \\ Kenitra, Morocco \\ 2 Regional Center for the Trades of Education and Training, Fez, Morocco \\ * Corresponding author's e-mail: rezoukisanae@gmail.com
}

\begin{abstract}
The present study aimed to study the diversity and density of the benthic fauna along the Inaouene wadi in relation to the variation of physicochemical parameters and heavy metals at six sampling stations representing the major part of the studied watercourses. The samples were taken during March and April 2019. The fauna recorded in this work consists of 2029 individuals corresponding to 39 families and 10 orders. The benthic population size showed that Oligochaetes, Diptera, Heteroptera, Trichoptera and Ephemeroptera are dominant. The diversity indices of Shannon and Weaver, and Piélou show that station S6 favors a better development of macroinvertebrates. This is confirmed by the values of physicochemical parameters and studied noble metals lord which shows that the stations S1, S3, S4 have poor water quality, compared to S6 and S5, the waters of which are of good quality, reflecting the self-purifying action of the watercourses between Wadi Amlil and Idriss I dam.
\end{abstract}

Keywords: macroinvertebrates, biological metrics, water quality, Inaouene wadi

\section{INTRODUCTION}

The aquatic ecosystems are characterized by a high biological productivity, a rich biodiversity and a multitude of ecological processes (Higler, 2009). The benthic macroinvertebrates represent an important part of the river biocenosis (Tenkiano, 2017), in the last few years, the knowledge on their occurrence in Moroccan water ecosystems has been a major concern for naturalists, scientists and development officials (Amrani et al., 2006). Benthic macro organisms are widely used today as bioindicators for their ability to reflect different disturbances in aquatic ecosystems. Adandedjan et al. (2013); Lenat \& Resh (2001); Bass (2003) and Lencioni \& Rossaro (2005) have shown that there are species that are considered excellent tools for the assessment of freshwater pollution and are a good indicator of environmental changes.
Inaouene wadi is one of the main watercourses in Morocco; it plays a very important role in the irrigation of hundreds of agricultural lands, the regulation of the climate, the maintenance of the habitats of benthic macro invertebrates and the local economic development. It is evident that the pollution of these rivers leads to environmental degradation (Smith et al., 2006; Wu et al., 2010), degradation of biodiversity (Dudgeon et al., 2006), as well as a decline in ecosystem services (Ripl and Wolter, 2005).

The composition of faunal communities depends on the interaction of physical and biological factors. Different insect assemblages in a stream are profoundly influenced by noble metals and physical factors such as current velocity, dissolved oxygen, temperature, and water conductivity (Bilton et al., 2001; Zhang et al., 2014; Free et al., 2009; Cai et al., 2017a) and biological factors 
such as plantlets, macrophytes, and periphytons (Cai et al., 2012b; Yan et al., 2014)

The ecosystems and waterways are severely impacted and damaged by economic development and anthropization (Armitage, 1995). All those activities affect the water quality, nutrient levels, and the macroinvertebrate community. The critical factors that influence the spatiotemporal distribution of organisms are an interesting topic in ecological studies (Garrido et al., 1994).

This study aimed to evaluate the level of pollution of aquatic ecosystems and to identify the environmental factors that influence the diversity of macrofauna in the different stations studied along the Inaouene wadi

\section{MATERIAL AND METHOD}

\section{Description of the study area and studied rivers}

The watershed of Inaouène wadi is a sub-basin of the great basin of Sebou, it covers the area of $3320 \mathrm{~km}^{2}$. The Inaouene wadi takes its source at Bab Merzoka (Taza) to the downstream where it meets Sebou at the rural town of Al Ouadayne (Molay Yaacoub), it is the second main tributary of the Sebou wadi after Ouargha wadi (Fig. 1).

In order to carry out this study, six stations were explored along the wadi, taking into consideration different criteria such as the source of agricultural and industrial pollution, direction of flow, accessibility etc. (Fig. 1, Table 1). The coordinates were recorded using a 72-hour handheld GPS counter (GARMIN, China).

\section{Water sampling and analysis}

\section{Environmental characteristics}

Stream substrates, shown in Table 1, were classified according to their diameter based on the classification of Tacher el al., (2010) fine sand (diameter $<2 \mathrm{~mm}$ ), coarse sand $(2-25 \mathrm{~mm})$, stones $(25-250 \mathrm{~mm})$ and rocks $(>250 \mathrm{~mm})$, the percentage of substrate cover was assessed visually (Table 1) (Touron-Poncet et al., 2014). The average flow velocity was measured using the formula $\mathrm{V}=\mathrm{d} / \mathrm{t}$ with $\mathrm{V}$ : average velocity in $\mathrm{m} / \mathrm{s}$, $\mathrm{d}$ : distance between 2 points in meters and t: time per second. The current velocities were classified according to the Berg (1948) scale: very slow $(\mathrm{v}<10 \mathrm{~cm} / \mathrm{s})$, slow $(10<\mathrm{v}<25 \mathrm{~cm} / \mathrm{s})$, moderate $(25<\mathrm{v}<50 \mathrm{~cm} / \mathrm{s})$, fast $(\mathrm{v}>50 \mathrm{~cm} / \mathrm{s})$ (Table 2).

\section{Physicochemical characteristics}

The physicochemical analysis of the water was performed on the same day as the insect sampling (AFNOR, 2005): Temperature $\left(\mathrm{T}^{\circ} \mathrm{C}\right)$, Hydrogen Potential (pH), Electrical Conductivity

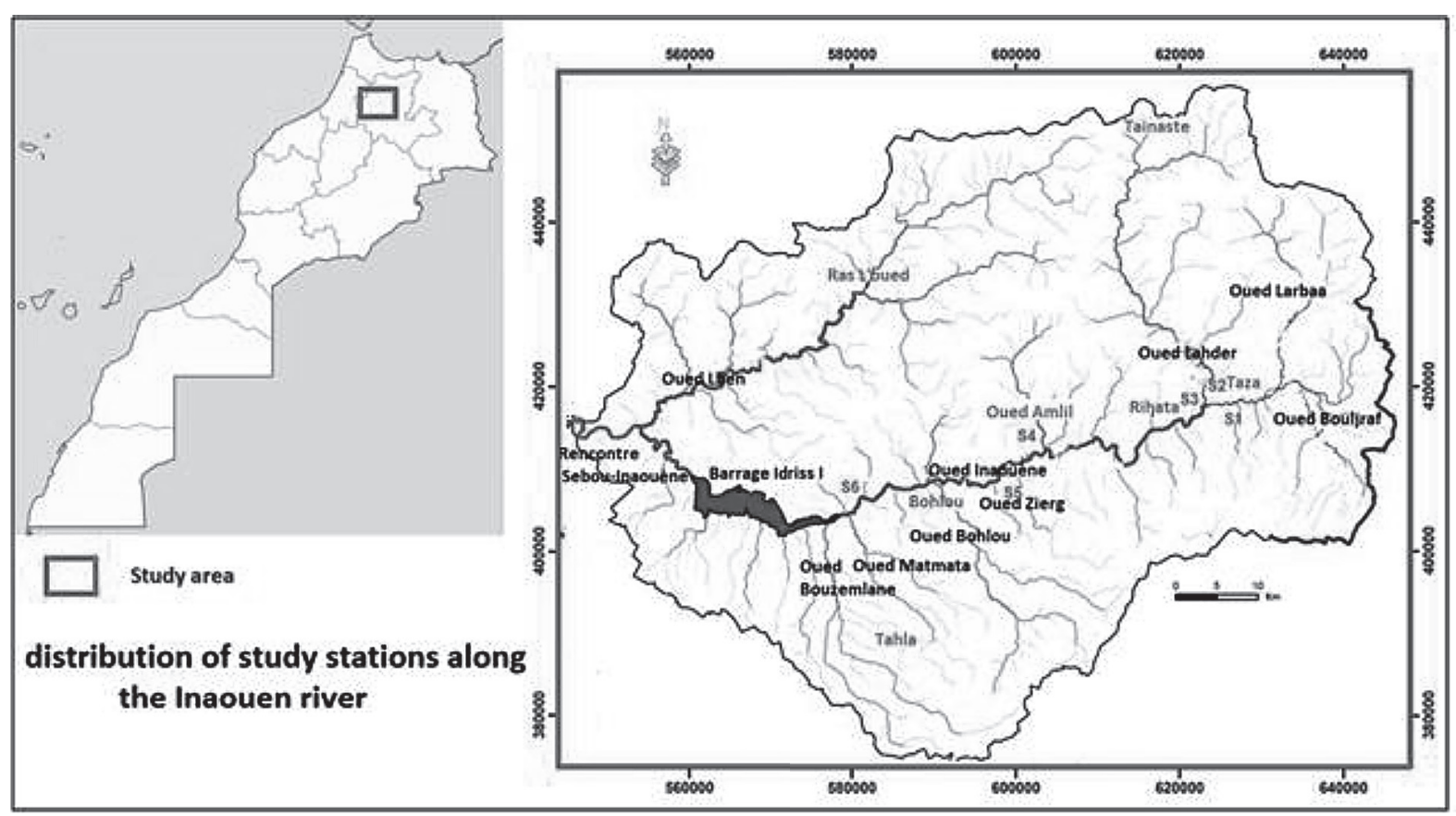

Fig. 1. distribution of study stations along Inaouene wadi 
Table 1. Geographical location of the study stations

\begin{tabular}{|c|c|c|c|c|c|c|}
\hline \multirow{2}{*}{ No. } & \multirow{2}{*}{ Station name } & \multicolumn{2}{|c|}{ C. Geographic } & \multirow{2}{*}{$\begin{array}{l}\text { Altitude } \\
(\mathrm{m})\end{array}$} & \multirow{2}{*}{ Substrat dominat } & \multirow{2}{*}{ Human pressure } \\
\hline & & Latitude N & Longitude W & & & \\
\hline S1 & $\begin{array}{l}\text { The Wadi Larbaâ located at } \\
\text { RN6, } 35000 \text { Bab Marzouka }\end{array}$ & $34^{\circ} 13^{\prime} 58.841^{\prime \prime}$ & $4^{\circ} 3^{\prime} 42.36^{\prime \prime}$ & 483 & coarse sand, stone & $\begin{array}{l}\text { entropic / } \\
\text { agricultural }\end{array}$ \\
\hline S2 & $\begin{array}{l}\text { The Wadi Lahdar situe à RN6, } \\
35000 \text { Bab Marzouka }\end{array}$ & $34^{\circ} 14^{\prime} 3.659^{\prime \prime}$ & $4^{\circ} 3^{\prime} 50.099^{\prime \prime}$ & 483 & $\begin{array}{l}\text { coarse sand, fine sand, } \\
\text { stone }\end{array}$ & agricultural \\
\hline S3 & $\begin{array}{l}\text { Upstream of Inaouene located } \\
\text { at } 35000 \text { Bab Marzouka, }\end{array}$ & $34^{\circ} 13^{\prime} 40.942^{\prime \prime}$ & $4^{\circ} 4^{\prime} 7.528^{\prime \prime}$ & 483 & $\begin{array}{l}\text { coarse sand, fine sand, } \\
\text { stone }\end{array}$ & forest / agricultural \\
\hline S4 & $\begin{array}{l}\text { Inaouen upstream located in } \\
\text { Ghiata Al Gharbia }\end{array}$ & $34^{\circ} 11^{\prime} 57.472^{\prime \prime}$ & $4^{\circ} 12^{\prime} 23.08^{\prime \prime}$ & 304 & fine sand, stone & $\begin{array}{l}\text { entropic / } \\
\text { agricultural }\end{array}$ \\
\hline S5 & $\begin{array}{l}\text { Wadi Zireg located in Caïdat } \\
\text { de Bouhlou }\end{array}$ & $34^{\circ} 09^{\prime} 54.2^{\prime \prime}$ & $4^{\circ} 20^{\prime} 24.5^{\prime \prime}$ & 367 & fine sand & agricultural \\
\hline S6 & $\begin{array}{l}\text { Inaouen Downstream located } \\
\text { at RP5418, Matmata }\end{array}$ & $34^{\circ} 7^{\prime} 31.989^{\prime \prime}$ & $4^{\circ} 30^{\prime} 09.6 »$ & 273 & fine sand & agricultural \\
\hline
\end{tabular}

(EC), Dissolved Oxygen (DO), measured in situ using a multi -parameter (Consort multi- parameter analyzer). Sulfates ( $\left.\mathrm{SO}_{4}^{2-}\right)$, Ortho-phosphates $\left(\mathrm{PO}_{4}\right)$ and Biological Oxygen Demand $\left(\mathrm{BOD}_{5}\right)$ were determined according to Rodier's analysis protocol (Rodier 1996). The total hardness $\left(\mathrm{F}^{\circ}\right)$ of the water was determined by volumetric titration with EDTA $0.2 \mathrm{~N}$, whereas Nitrates $\left(\mathrm{NO}^{3-}\right)$ and Ammonium $\left(\mathrm{NH}^{4+}\right)$ were determined by spectrophotometry (Table 2). The determination of trace metal elements ( $\mathrm{Mg}, \mathrm{Co}, \mathrm{Cu}, \mathrm{Fe}, \mathrm{Ni}, \mathrm{Pb}, \mathrm{Cr}$, and $\mathrm{Zn})$ was performed using Inductively Coupled Plasma Emission Spectrometry (ICP-AES) at the CNRST laboratory in Rabat (Table 3).

\section{Benthos sampling}

For the faunistic study, the sampling of the invertebrate macrofauna consists of collecting the greatest faunal diversity representative of the habitats to be studied in order to obtain a most complete assessment of the taxa present in the rivers. Sampling of the benthos is carried out between March and May 2019, the main tool used for sampling the fauna is a "Surber" type net with a mesh opening $(500 \mu \mathrm{m})$. The samplings carried out thus correspond to the otic facies according to the definition of Tuffery and Vernaux (1967). Each sample is made up of 8 elementary samples following a transept from one bank to the other (except for stations that are too deep).

At each station, sampling was distributed in proportion to the relative extent of the different habitat types, in order to obtain the largest possible number of taxa. Each habitat is characterized by its substrate type and current velocity (Table 1 and 2).

The samples in labeled jars were fixed with a formalin solution of final concentration of $10 \%$.
In the laboratory, the samples were rinsed on a $500 \mu \mathrm{m}$ mesh sieve, in order to eliminate as much remaining fine substrate and coarse elements as possible. The identification of the fauna is done under a binocular loupe. The organisms are manipulated with fine tweezers and mounted needles. Determination keys were used to recognize the individuals (Tachet et al., 2006)

\section{Biological metrics}

For each benthic insect family, the abundancefrequency ratio (AF \%) was calculated as a percentage of the number of individuals in a considered family to the total number of all individuals.

$$
F=\frac{n}{N} \times 100
$$

For each benthic insect community, the total taxonomic richness $(\mathrm{S})$ was calculate

$$
D=\frac{\sum n(n-1)}{N(N-1)}
$$

The Shannon-Weaver diversity index H', with ni: the number of taxa $i$ and $N$ : the total number:

$$
H^{\prime}=-\sum((n i / N) * \operatorname{Ln}(n i / N))
$$

Pielou's regularity index J', with Hmax $=\log 2 \mathrm{~S}$; Magurran 2004):

$$
J^{\prime}=H^{\prime} / H \max
$$


Table 2. Physicochemical characteristics of the water at the study sites

\begin{tabular}{|c|c|c|c|c|c|c|c|c|c|c|}
\hline Station & $\mathrm{T}\left({ }^{\circ} \mathrm{C}\right)$ & $\begin{array}{c}\mathrm{V} \\
(\mathrm{cm} / \mathrm{s})\end{array}$ & $\mathrm{pH}$ & $\begin{array}{c}\mathrm{CE} \\
(\mathrm{cm} / \mathrm{s})\end{array}$ & $\begin{array}{c}\mathrm{DBO} 5 \\
\left(\mathrm{mg} \mathrm{O}_{2} / \mathrm{l}\right)\end{array}$ & $\begin{array}{l}\text { Disolved } \mathrm{O}_{2} \\
\quad(\mathrm{mg} / \mathrm{l})\end{array}$ & Sulphates & $\begin{array}{l}\mathrm{PO}_{4}^{3-} \\
(\mathrm{mg} / \mathrm{l})\end{array}$ & $\begin{array}{c}\text { Nitratres } \\
\mathrm{NO}^{3-} \\
(\mathrm{mg} / \mathrm{l})\end{array}$ & $\begin{array}{c}\text { Ammoniacal } \\
\text { nitrogen }\end{array}$ \\
\hline $\mathrm{S} 1$ & $23.1 \pm 0.1^{a}$ & fast & $8.2 \pm 0.1^{a}$ & $2000 \pm 24^{a}$ & $520.9 \pm 9.95^{a}$ & $3.02 \pm 0.09^{\mathrm{a}}$ & $910 \pm 11.37^{a}$ & $7.8 \pm 0.06^{\mathrm{a}}$ & $22.7 \pm 0.25^{a}$ & $0.79 \pm 0.1^{a}$ \\
\hline $\mathrm{S} 2$ & $26.9 \pm 0.1^{\mathrm{ab}}$ & moderate & $8.1 \pm 0.1^{\mathrm{a}}$ & $2894 \pm 19^{b}$ & $17.38 \pm 4.92^{\mathrm{b}}$ & $5 \pm 0.09^{b}$ & $\begin{array}{c}488 \pm \\
10.45^{b}\end{array}$ & $1.02 \pm 0.03^{b}$ & $7.6 \pm 0.09^{b}$ & $0.18 \pm 0.07^{a}$ \\
\hline S3 & $26 \pm 0.2^{\mathrm{a}}$ & fast & $8.05 \pm 0.1^{b}$ & $2099 \pm 19^{a}$ & $516.76 \pm 22.2^{a}$ & $2.23 \pm 0.06^{\mathrm{ac}}$ & $\begin{array}{l}875 \pm \\
10.01^{\circ}\end{array}$ & $6.45 \pm 0.08^{c}$ & $21 \pm 0.43^{c}$ & $0.65 \pm 0.04^{c}$ \\
\hline S4 & $26.3 \pm 0.19^{\mathrm{ab}}$ & fast & $\begin{array}{l}7.9 \pm \\
0.04^{b}\end{array}$ & $1859 \pm 22^{\mathrm{Ad}}$ & $447.27 \pm 31.2^{c}$ & $3.02 \pm 0.08^{c}$ & $\begin{array}{c}580.6 \pm \\
14.2^{\mathrm{d}}\end{array}$ & $\begin{array}{l}4.89 \pm \\
0.06^{d}\end{array}$ & $21.21 \pm 0.24^{d}$ & $0.75 \pm 0.1^{\mathrm{a}}$ \\
\hline S5 & $27.4 \pm 0.09^{b}$ & fast & $\begin{array}{l}8.1 \pm \\
0.03^{\mathrm{a}}\end{array}$ & $214.3 \pm 11.59^{c}$ & $59.1 \pm 1.99^{b}$ & $5.01 \pm 0.09^{b}$ & $301 \pm 11^{f}$ & $1.68 \pm 0.04^{\mathrm{e}}$ & $7.04 \pm 0.03^{f}$ & $0.1 \pm 0.04^{d}$ \\
\hline S6 & $29,5 \pm 0,91^{b}$ & fast & $\begin{array}{l}7,9 \pm \\
0,01^{\mathrm{c}}\end{array}$ & $1308 \pm 11^{d}$ & $289 \pm 14,64^{d}$ & $7,40 \pm 0,05^{b}$ & $\begin{array}{c}689 \pm \\
10,75^{c}\end{array}$ & $2,5 \pm 0,05^{f}$ & $15,23 \pm 0,12$ & $0,71 \pm 0,1$ ac \\
\hline
\end{tabular}

Family Level Biotic Index (FBI):

$$
F B I=\sum_{i=1}^{F} n i t i / N
$$

FBI and the percentage of tolerant individuals (PTO-ind) were evaluated to describe the diversity and characterize the tolerance status of benthic macroinvertebrate assemblages in different sampling sites as well as the presence of organic pollution.

\section{Statistical analysis}

Statistical analyses were performed on the data for both single-variable (correlation tests) and multivariate (similarity tests and principal component analysis) to determine the different correlations between these parameters.

\section{RESULTS}

\section{Environmental variables}

The variations of the environmental variables measured in the different stations and the different habitat groups are shown in Table 2. The temperature does not show great variations from one station to another with the values varying between $23.1^{\circ} \mathrm{C}$ and $27.4^{\circ} \mathrm{C}$, The $\mathrm{pH}$ is relatively basic in all stations varies between 7.8 and 8.5, for The values of water conductivity decreases significantly from upstream to downstream with a maximum value of $2894 \mu \mathrm{s} / \mathrm{cm}$ recorded at S2 and minimum of $214.3 \mu \mathrm{s} / \mathrm{cm}$ recorded at S5, The oxygen content varies from one station to another with a maximum value of $7.08 \mathrm{mg} / \mathrm{l}$ recorded at
$\mathrm{S} 2$ and a minimum value of $2.23 \mathrm{mg} / \mathrm{l}$ recorded at $\mathrm{S} 3, \mathrm{BOD}_{5}$ also varies from station to station with a maximum value of $520.9 \mathrm{mg} \mathrm{O}_{2} / 1$ recorded at $\mathrm{S} 1$ and a minimum value of $2.9 \mathrm{mg} \mathrm{O} / 1$ recorded at S6, the sulfate content decreases from upstream to downstream with values varying between 910 and 57 , for $\mathrm{PO}_{4}^{3-}$ maximum values of $7.8 \mathrm{mg} / 1$ and $6.45 \mathrm{mg} / 1$ were obtained in $\mathrm{S} 1$ and $\mathrm{S} 3$, respective$1 \mathrm{y}$, and minimum values of $1.02 \mathrm{mg} / 1,4.89 \mathrm{mg} / \mathrm{l}$, $1.68 \mathrm{mg} / 1$ and $0.6 \mathrm{mg} / 1$ were recorded in $\mathrm{S} 2, \mathrm{~S} 4$, $\mathrm{S} 5$ and $\mathrm{S} 6$ respectively. The maximum values of nitrate $\mathrm{NO}^{3-}$ reaching $22.7 \mathrm{mg} / 1,21 \mathrm{mg} / \mathrm{l}$ and $21.21 \mathrm{mg} / 1$ were recorded in S1, S3 and S4 respectively, whereas minimum values of $7.6 \mathrm{mg} / \mathrm{l}$, $7.04 \mathrm{mg} / 1$ and $0.55 \mathrm{mg} / \mathrm{l}$ recorded in S2, S5 and S6 and for ammonia nitrogen the values vary between a minimum of 0.08 and a maximum of 0.75 . As for the speed of the river, it is fast in all the stations.

In this study, the existence of five essential trace elements ( $\mathrm{Ag}, \mathrm{Fe}, \mathrm{Pb}, \mathrm{Cu}$, and $\mathrm{Zn})$ was investigated. Minerals are essential elements for aquatic living beings, but if the organism excessively takes these elements from the external environment, they will damage their health. (Mutlu and Kurnaz, 2017), Pb, as an example, is dangerous for different life forms due to its toxicity ( $\mathrm{Fa}$ toki et al., 2002).

The concentrations of heavy metals at the different stations are shown in Table 3. The heavy metal concentrations vary spatially in a significant way from one station to another with high concentrations upstream and gradually decreasing towards the downstream.

\section{Community structure and diversity of insects}

With a total of 4140 individuals distributed on 10 orders and 39 families, Ephemeroptera was the most diverse group with 8 families. Diptera 
Table 3. Heavy metals in different stations

\begin{tabular}{|c|c|c|c|c|c|}
\hline Station & $\mathrm{Ag}$ & $\mathrm{Fe}$ & $\mathrm{Pb}$ & $\mathrm{Zn}$ & $\mathrm{Cu}$ \\
\hline $\mathrm{S} 1$ & $0.092 \pm 0.007^{\mathrm{a}}$ & $0.72 \pm 0.07^{\mathrm{a}}$ & $0.09 \pm 0.02^{\mathrm{a}}$ & $1.88 \pm 0.038^{\mathrm{a}}$ & $0.012 \pm 0.002^{\mathrm{a}}$ \\
\hline $\mathrm{S} 2$ & $0.049 \pm 0.003^{\mathrm{a}}$ & $0.05 \pm 0.001^{\mathrm{b}}$ & $0.049 \pm 0.003^{\mathrm{a}}$ & $0.0053 \pm 0.001^{\mathrm{b}}$ & $0.013 \pm 0.025^{\mathrm{a}}$ \\
\hline $\mathrm{S} 3$ & $0.06 \pm 0.04^{\mathrm{a}}$ & $0.49 \pm 0.015^{\mathrm{c}}$ & $0.045 \pm 0.04^{\mathrm{a}}$ & $1.13 \pm 0.03^{\mathrm{c}}$ & $0.01 \pm 0.001^{\mathrm{a}}$ \\
\hline $\mathrm{S} 4$ & $0.093 \pm 0.015^{\mathrm{a}}$ & $0.42 \pm 0.04^{\mathrm{d}}$ & $0.08 \pm 0.004^{\mathrm{a}}$ & $1.08 \pm 0.05^{\mathrm{d}}$ & $0.011 \pm 0.001^{\mathrm{a}}$ \\
\hline $\mathrm{S} 5$ & $0.049 \pm 0.005^{\mathrm{b}}$ & $0.025 \pm 0.004^{\mathrm{e}}$ & $0.05 \pm 0.001^{\mathrm{a}}$ & $0.005 \pm 0.001^{\mathrm{b}}$ & $0.011 \pm 0.002^{\mathrm{a}}$ \\
\hline $\mathrm{S} 6$ & $0.05 \pm 0.004^{\mathrm{a}}$ & $0.24 \pm 0.03^{\mathrm{c}}$ & $0.05 \pm 0.002^{\mathrm{a}}$ & $0.98 \pm 0.11^{\mathrm{a}}$ & $0.012 \pm 0.002^{\mathrm{a}}$ \\
\hline
\end{tabular}

dominate, representing $33.21 \%$ of the total abundance followed by Ephemeroptera $11.18 \%$. Trichoptera and Plecoptera represented $2.51 \%$ and $2.15 \%$ of the total abundance respectively, Coleoptera, Trombidiformes, Hemiptera, Nemathelminthes, Megaptera and Odonata were less abundant with $0.27 \%, 0.024 \%, 0.15 \%, 0.19 \%$, $0.17 \%$ and $0.15 \%$ of the total abundance, respectively. The most abundant families were: Simuliidae (16.79\%), Chaoboridae(10.46\%), Baetidae $(7.59 \%)$ (Table 4). In terms of number of families, station S2 is the least diverse while station $\mathrm{S} 5$ is the most diverse.

\section{Biological metrics}

Five biological metrics were measured for each station: total taxon richness (D), ShannonWeaver diversity index $\left(\mathrm{H}^{\prime}\right)$, Pielou evenness index (J'), family level biotic index (FBI) and percentage of tolerant individuals PTO-ind. D, J'and $\mathrm{H}^{\prime}$ were generally used to indicate community diversity. FBI and PTO-ind were used to reflect environmental pollution. These parameters varied among habitat types and sampling sites (Fig. 2).

\section{Multivariate analysis of the studied parameters}

The Principal Component Analysis (PCA) showed that environmental variables and heavy metals have some influence on the distribution of the 39 families of invertebrate macrofauna. The physico-chemical parameters, such as dissolved oxygen, $\mathrm{BOD}_{5}, \mathrm{SO}_{4}^{2-}, \mathrm{PO}^{4-}, \mathrm{NH}^{4+}, \mathrm{EC}, \mathrm{pH}$ and $\mathrm{T}^{\circ}$ as well as the following heavy metals: $\mathrm{Pb}, \mathrm{Fe}$, $\mathrm{Ag}, \mathrm{Zn}$ and $\mathrm{Cu}$ were selected as the main parameters affecting the community structure of benthic macroinvertebrates.

The ordination of this PCA in the factorial plane 1-2 $(33.5 \%)$ allows a clear division of the communities into three major groups (Fig. 3 and 4). Group 1 is composed of nine taxa
(Hydropsychidae, Philopotamidae, Helicopsychidae, Polycentropodidae, Brachycentridae, Ameletidae, Ephemerellidae, Leptophlebiidae and Caenidae) that are favored by high dissolved oxygen and temperature levels and mainly identified in the downstream station (S6). Group 2 consists of 9 taxa that develop in the environments characterized by high levels of $\mathrm{BOD}_{5}$, electrical conductivity, $\mathrm{pH}, \mathrm{NO}^{3-} \mathrm{SO}_{4}^{3-}, \mathrm{PO}^{4-}$ and $\mathrm{NH}^{4+}$ and the presence of high concentrations of heavy metals $(\mathrm{Pb}, \mathrm{Ag}, \mathrm{Cu}, \mathrm{Zn}$ and $\mathrm{Fe})$. These are mainly the taxa: Veliidae, Noteridae, Metretopodiae, Elmidae, Hydrophilidae, Syrphydae, Ceratopogonidae, Baetidae, Chironomidae and Taeniopterygidae. These taxa develop especially in the upstream stations (S1, S3 and S4). Group 3 consists of nine taxa (Leuctridae, Odontoceridae, Nemouridae, Capniidae, Dytiscidae, Simuliidae, Hydrachnidae, Nematodes and Pteronarcydae) from station S5 in a rural area, characterized by the absence of polishing antropic activities with low levels of $\mathrm{BOD}_{5}, \mathrm{NO}^{3-} \mathrm{SO}_{4}^{3-}, \mathrm{PO}^{4-}$ and $\mathrm{NH}^{4+}$ and acceptable values of heavy metals.

\section{DISCUSSION}

The degradation of aquatic ecosystems in Morocco presents a major challenge for environmental protection. Development activities, such as urbanization, the development of medium and large-scale industries, and the intensification of agricultural practices near streams and rivers are causing an alteration of water quality and affect the overall health of aquatic ecosystems (Karrouch et al., 2018; Akalu 2011; Beneberu et al., 2014). In the study area, there are several urban, industrial, artisanal and agricultural activities. However, most of these activities do not have any effluent treatment system and discharge their waste directly in the tributaries of the Inaouene wadi (El Haji et al., 2012). Several works conducted in Morocco using physicochemical and 
Table 4. Distribution of taxa in the different stations

\begin{tabular}{|c|c|c|c|c|c|c|c|c|}
\hline Order & Family & S1 & $\mathrm{S} 2$ & S3 & S3.A & S5 zirk & $\mathrm{S} 13$ & $\mathrm{AF} \%$ \\
\hline \multirow{6}{*}{ Tricopteres } & Hydropsychidae & 4 & 0 & 0 & 17 & 40 & 30 & 2.198 \\
\hline & Odontoceridae & 0 & 0 & 0 & 0 & 2 & 0 & 0.048 \\
\hline & Helicopsychidae & 0 & 0 & 0 & 0 & 0 & 2 & 0.048 \\
\hline & Philopotamidae & 0 & 0 & 0 & 0 & 0 & 2 & 0.048 \\
\hline & Brachycentridae & 0 & 0 & 0 & 0 & 0 & 1 & 0.145 \\
\hline & Polycentropodidae & 0 & 0 & 0 & 0 & 0 & 6 & 0.024 \\
\hline & Total Tricopteres & 4 & 0 & 0 & 17 & 42 & 41 & 2.512 \\
\hline \multirow{7}{*}{ Plecopteres } & Leuctridae & 4 & 3 & 17 & 0 & 43 & 8 & 1.812 \\
\hline & Taeniopterygidae & 4 & 2 & 0 & 0 & 2 & 0 & 0.193 \\
\hline & Nemouridae & 0 & 0 & 0 & 0 & 1 & 0 & 0.024 \\
\hline & Capniidae & 0 & 0 & 0 & 0 & 1 & 0 & 0.024 \\
\hline & Pteronarcydae & 0 & 0 & 0 & 0 & 1 & 0 & 0.024 \\
\hline & Chloroperlidae & 0 & 0 & 0 & 0 & 2 & 0 & 0.024 \\
\hline & Nemouridae & 0 & 0 & 0 & 0 & 1 & 0 & 0.048 \\
\hline & Total Plecopteres & 8 & 5 & 17 & 0 & 51 & 8 & 2.15 \\
\hline \multirow{6}{*}{ Coleopteres } & Elmidae & 3 & 0 & 0 & 1 & 0 & 0 & 0.1 \\
\hline & Dryopidae & 0 & 0 & 0 & 0 & 1 & 0 & 0.024 \\
\hline & Haliplidae & 0 & 0 & 0 & 0 & 1 & 0 & 0.024 \\
\hline & Dytiscidae & 0 & 0 & 0 & 1 & 2 & 0 & 0.072 \\
\hline & Hydrophilidae & 0 & 0 & 0 & 1 & 0 & 0 & 0.024 \\
\hline & Noteridae & 0 & 0 & 0 & 1 & 0 & 0 & 0.024 \\
\hline \multicolumn{2}{|r|}{ Total Coleopteres } & 3 & 0 & 0 & 4 & 4 & 0 & 0.266 \\
\hline Hemipteres & Veliidae & 0 & 0 & 0 & 1 & 0 & 0 & 0.024 \\
\hline \multicolumn{2}{|r|}{ Total Hemipteres } & 0 & 0 & 0 & 1 & 0 & 0 & 0.024 \\
\hline Trombidiformes & Hydrachnidae & 0 & 1 & 0 & 0 & 5 & 0 & 0.145 \\
\hline \multicolumn{2}{|r|}{ Total Trombidiformes } & 0 & 1 & 0 & 0 & 5 & 0 & 0.145 \\
\hline \multirow{6}{*}{ Dipteres } & Simuliidae & 50 & 0 & 239 & 101 & 301 & 4 & 16.787 \\
\hline & Ceratopogonidae & 18 & 0 & 76 & 2 & 12 & 0 & 2.609 \\
\hline & Chaoboridae & 96 & 0 & 323 & 10 & 4 & 0 & 10.459 \\
\hline & Syrphydae & 2 & 0 & 3 & 3 & 25 & 0 & 0.797 \\
\hline & Ephydridae & 6 & 0 & 0 & 0 & 0 & 0 & 0.145 \\
\hline & Chironomidae & 27 & 0 & 53 & 10 & 10 & 0 & 2.415 \\
\hline & Total Dipteres & 199 & 0 & 694 & 126 & 352 & 4 & 33.213 \\
\hline & Baetidae & 1 & 4 & 175 & 64 & 57 & 13 & 7.585 \\
\hline & Ephemerellidae & 0 & 0 & 7 & 0 & 9 & 10 & 0.628 \\
\hline & Ameletidae & 0 & 0 & 0 & 0 & 7 & 9 & 0.386 \\
\hline \multirow{5}{*}{ Ephéméroptreres } & Leptophlebiidae & 0 & 0 & 10 & 9 & 11 & 14 & 1.063 \\
\hline & Metretopodiae & 0 & 0 & 1 & 27 & 0 & 0 & 0.676 \\
\hline & Siphlonuridae & 0 & 0 & 0 & 4 & 0 & 0 & 0.0967 \\
\hline & Caenidae & 0 & 0 & 0 & 10 & 0 & 20 & 0.725 \\
\hline & Isonychidae & 0 & 0 & 0 & 0 & 0 & 1 & 0.024 \\
\hline \multicolumn{2}{|r|}{ Total Ephéméroptreres } & 1 & 4 & 193 & 114 & 84 & 67 & 11.184 \\
\hline \multirow[t]{2}{*}{ Némathelminthes } & Nematodes & 3 & 0 & 0 & 0 & 5 & 0 & 0.193 \\
\hline & Total Nemathelmintes & 3 & 0 & 0 & 0 & 5 & 0 & 0.193 \\
\hline \multirow[t]{2}{*}{ Mégaptère } & Sialidae & 0 & 0 & 0 & 0 & 2 & 0 & 0.048 \\
\hline & Corydalidae & 0 & 0 & 0 & 0 & 0 & 5 & 0.121 \\
\hline \multicolumn{2}{|r|}{ Total mégaptère } & 0 & 0 & 0 & 0 & 2 & 5 & 0.17 \\
\hline \multirow{2}{*}{\multicolumn{2}{|c|}{$\begin{array}{r}\text { Cordulegastridae } \\
\text { Total Odonates }\end{array}$}} & 0 & 0 & 0 & 0 & 0 & 6 & 0.145 \\
\hline & & 0 & 0 & 0 & 0 & 0 & 6 & 0.145 \\
\hline
\end{tabular}

biological methods have shown that there is a serious pollution of rivers and streams, which are the likely causes of diseases in both animals and humans (Zalaghi et al., 2018). In streams in these regions, the dry period leads to the changes in abiotic conditions (parameters) that control the structure of biological communities (e.g., low oxygen, high temperatures, increased deposition of 

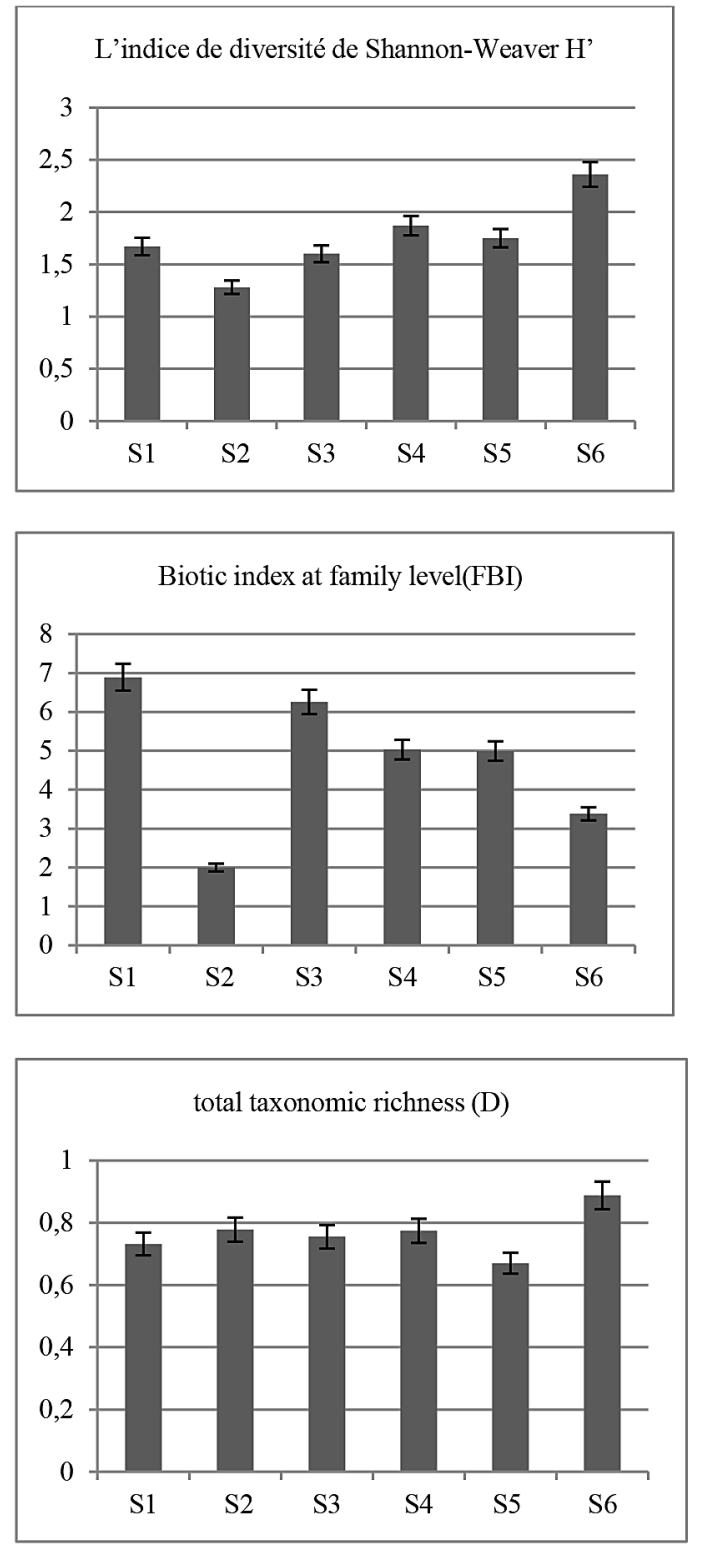
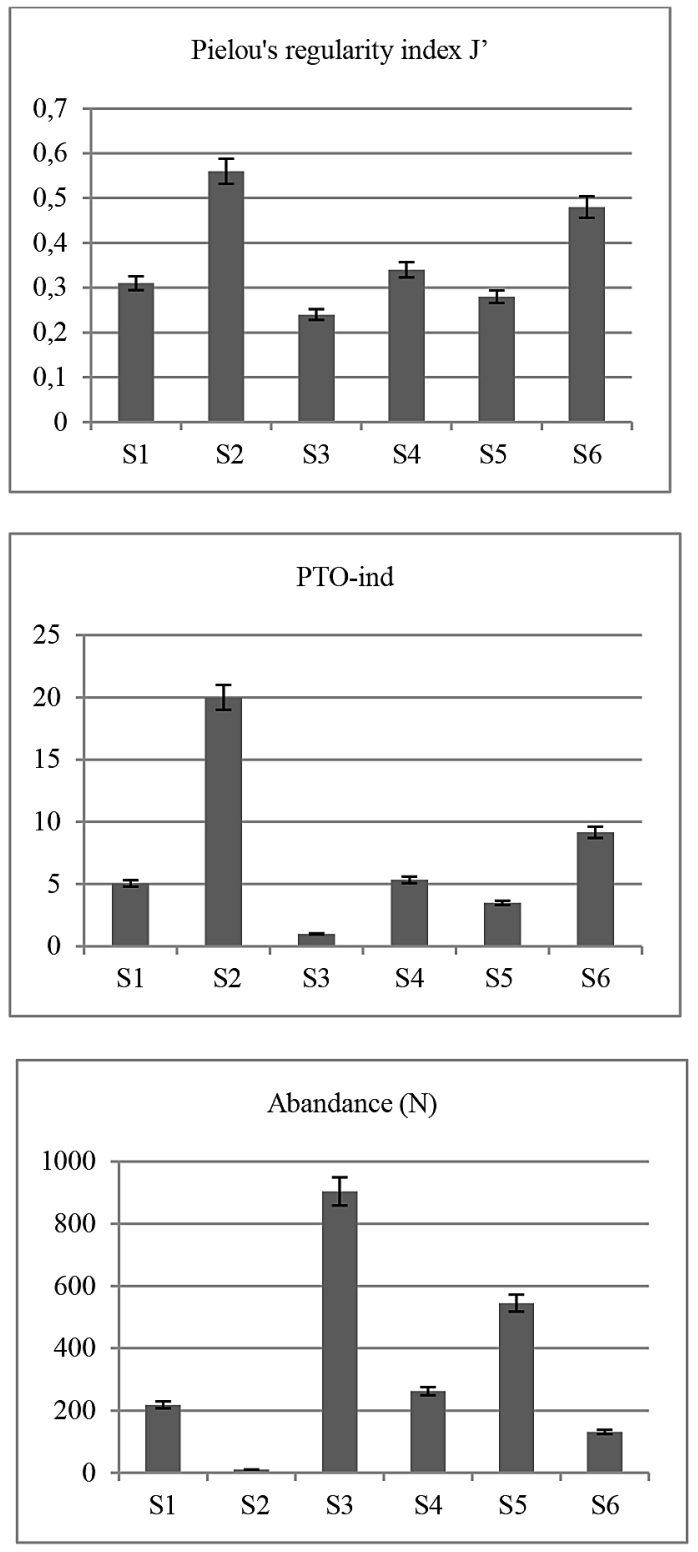

Fig. 2. Spatial variation of biological metrics for Inaouene wadi

fine particles, increased humidity, and increased temperature) sediments, increased algal production, and habitat loss (Gasith \& Resh, 1999).

The diversity of macrofauna observed in this region was significantly less diverse compared with other rivers, including those of the Sebou wadi (Fekhaoui et al., 1993), Boufekrane wadi (Chahlaoui et al., 1996; Aboulkacem et al., 2007; Karrouch, 2010), Boureg Reg wadi (EL Agbani, 1984) and Ouislane (Karrouch, 2010; Aboulkacem, 2007). This could be related to natural and/or anthropic factors influencing this watercourse. Indeed, the discharge of wastewater from the city of Taza through the wadi l'arbaa, as well as domestic discharges from other neighboring villages in the Inaouene wadi could, without doubt, considerably contribute to the distribution and diversity of this watercourse. In the same sense, the low taxonomic richness and abundance also found in different arid and semi-arid bioclimatic regions such as the one considered in this study (Bebba et al., 2015; Sellam et al., 2017) can be explained by unstable environmental conditions, including frequent lack of flow, insufficient running water levels, and high summer temperatures $\left(>35^{\circ} \mathrm{C}\right)$, leading to prolonged dry periods, with a negative impact on biodiversity that tends to be low (Arab et al., 2004). In terms of abundance, insect assemblages were dominated by Diptera, Ephemeroptera and Trichoptera. Diptera were much more 


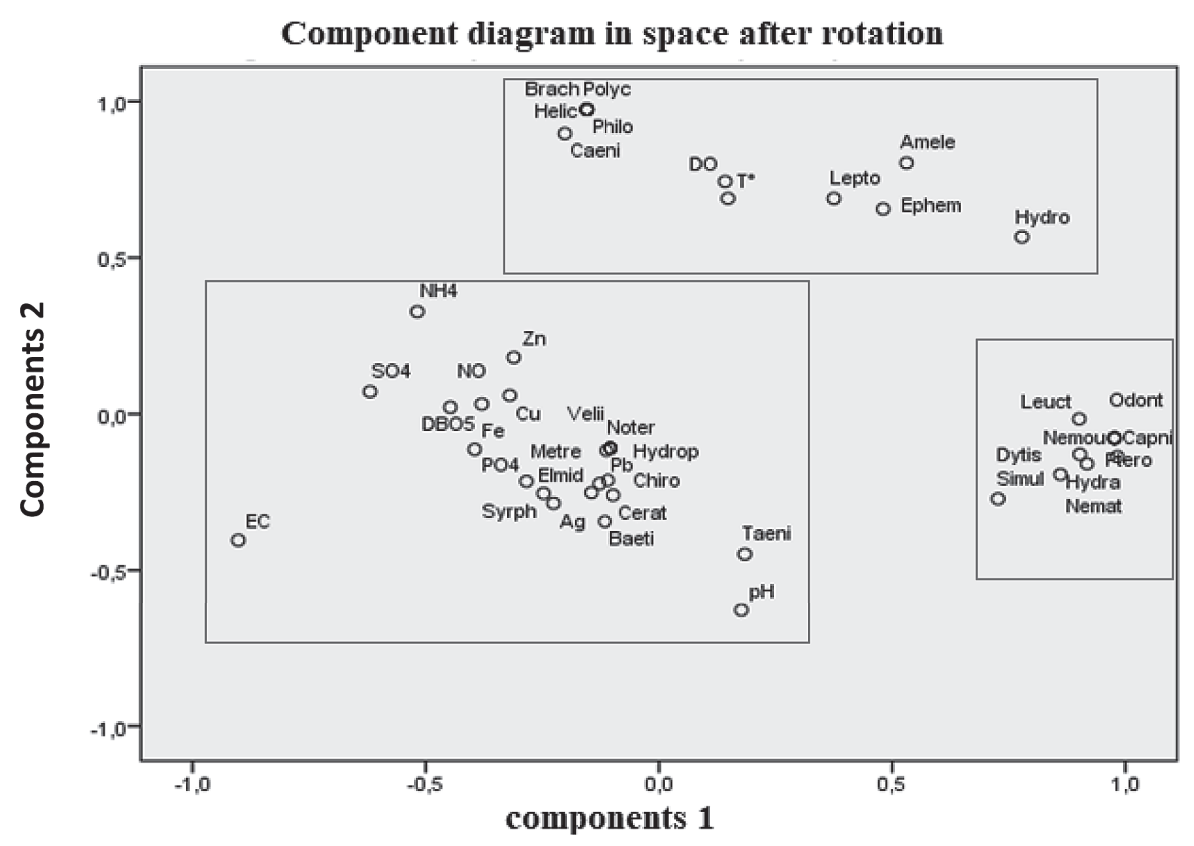

Fig. 3. PCA graphical representation showing the distribution of macro invertebrates according to physicochemical parameters and noble metals. Information :Brach= Brachycentridae, Polyc= Polycentropodidae, Helic $=$ Helicopsychidae, Philo $=$ Philopotamidae, Caeni $=$ Caenidae, Ameie $=$ Ameletidae, Lepto $=$ Leptophlebiidae,

Ephem $=$ Ephemerellidae, Hydro $=$ Hydropsychidae, Velii $=$ Veliidae, Noter $=$ Noteridae, Metre $=$ Metretopodiae, Hydrop $=$ Hydrophilidae, Chiro $=$ Chironomidae, $\mathrm{Syrph}=$ Syrphydae, Cerat $=$ Ceratopogonidae, Baeti $=$ Baetidae Taeni $=$ Taeniopterygidae, Leuct $=$ Leuctridae, Odont $=$ Odontoceridae, $\mathrm{Nemou}=\mathrm{Nemouridae}, \mathrm{Capni}=\mathrm{Capniidae}$,

Dytis $=$ Dytiscidae, Hydra= Hydrachnidae, Nemat $=$ Nematodes, simul= Simuliidae, ptero $=$ Pteronarcydae

dominant taxa, as was the case in other arid Mediterranean rivers in North Africa (Sellam et al., 2017). Simuliidae was the most abundant family found in station S3 and S5 with larvae adhering to stable substrates such as stones and sands (Tachet et al., 2010) and their tolerance to moderate levels of pollution (Augusto \& Marcos, 2010).

Station S6, which is located in the downstream of Inaouene, is characterized by a high biodiversity compared to the other stations, while

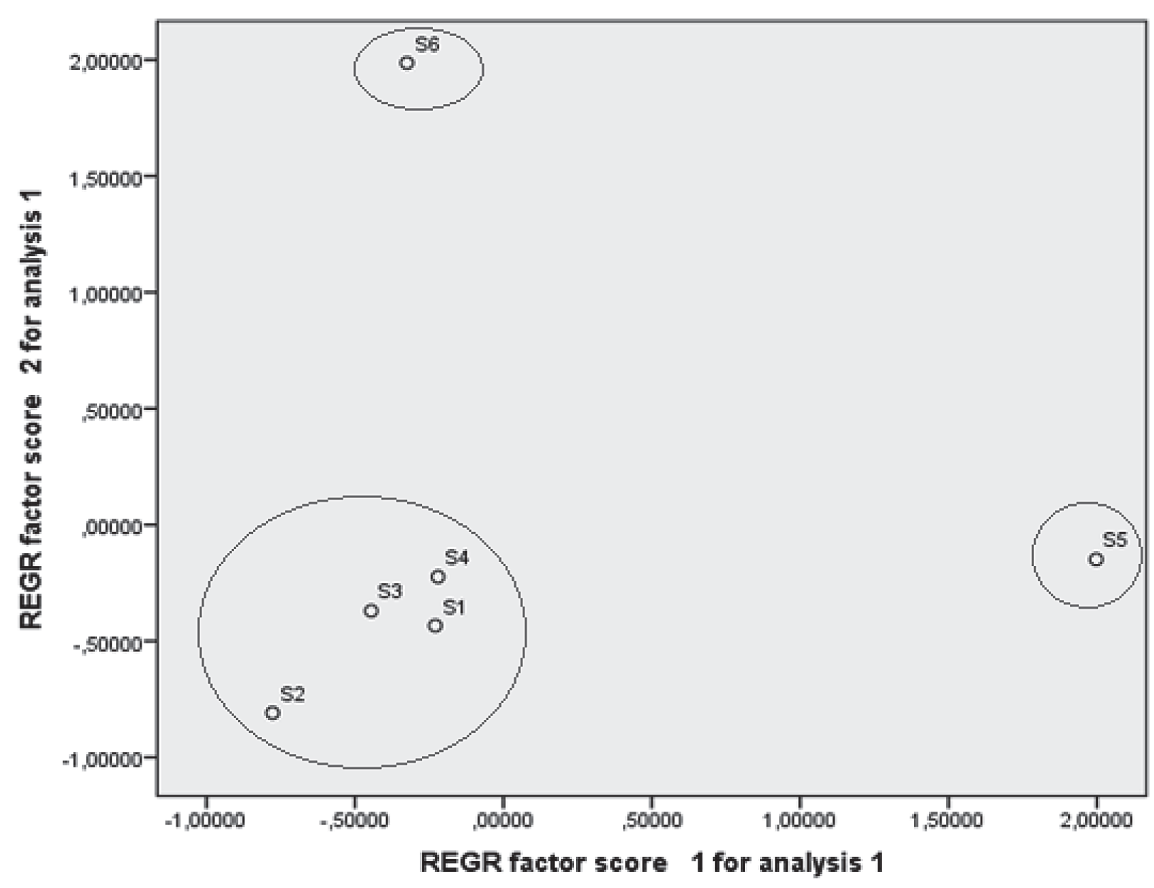

Fig. 4. PCA graphical representation showing the distribution of the study areas 
the fauna of $\mathrm{S} 2$ is less diverse. This difference in diversity between sites is probably due to physicochemical parameters, anthropic disturbances of the aquatic ecosystem, some sites having been exposed to domestic pollution. Similarly, Azrina et al. (2006) and Cereghino et al. (2002) noted that taxonomic richness is sensitive to human impact on aquatic ecosystems, particularly aquatic insects, which are good indicators of stream environmental conditions and are therefore very sensitive to pollution.

In the conducted research, six structural metrics were used to describe the tolerance level and diversity of macroinvertebrate assemblages at the study stations. The results showed that the values of these metrics varied from one station to another depending on the variation of physicochemical factors.

The taxonomic richness (D), abandonment $(\mathrm{N})$, and Shannon-Wiener index $\left(\mathrm{H}^{\prime}\right)$ indicate that the polluted sites tend to have lower diversity and abundance than the unpolluted sites; the familylevel biotic index (FBI) and the percentage of tolerant individuals (PTO-ind) indicate that benthic communities at the polluted sites tend to be more tolerant than those at the unpolluted sites. For the different stations, macroinvertebrate diversity and abundance showed significant correlations between the physicochemical and biological parameters. These results show that human activities can have remarkable effects on the characteristics of the benthic community by modifying the abiotic parameters of the habitat. If humans severely disrupt the living conditions of benthic communities, they become more monotonous and more tolerant to pollution. Many studies have highlighted the ecological changes that accompany environmental pollution in large, shallow lakes (Cai et al., 2017; Rodusky et al., 2008).

\section{CONCLUSIONS}

The Inaouene wadi is a regime characterized by irregularity of flows and by brutal hydrological events. The annual regime is marked by a weak flow in summer and autumn and by a strong flow in winter and spring. The fauna inventory carried out in the present study constitutes an important first data base. The fauna studied is characterized by a variable taxonomic diversity according to the degree of water pollution.
The fauna recorded in this work is composed of 2029 individuals corresponding to 39 families belonging to 10 orders of faunal groups (Annelids, arthropods). The number of benthic populations showed that Dipteres, Tricopteres, Plecopteres, Ephéméroptreres, are dominant. Odonates, mégaptère, Nemathelmintes, Trombidiformes, Hemipteres and Coleopteres constitute only a small fraction of the collected fauna.

The biological indices (Shannon and Equitability .....) used for the characterization of the Inaouene wadi waters, better discriminate the study stations according to their pollution level. The results obtained are in good agreement with the results obtained through the study of physicochemical characteristics and heavy metals. The biological diversity of macrofauna in the wadi depends on the physicochemical parameters at each station; it is strongly influenced by anthropogenic activities.

\section{REFERENCES}

1. Aboulkacem A. 2007. Étude hydrobiologique comparative des oueds Boufekrane et Ouislane à la traversée de la ville de Meknès. Impact sur la Sante et l'Environnement. Thèse d'Etat, Fac. Sciences. Université Moulay Ismail, Meknès (Maroc), p. 159.

2. Adandedjan D., Montcho A.S., Chikou A., Laleye Ph., Gourene G. 2013. Use of the self-organizing map (SOM) for the characterization of macrobenthic populations. Biological Reports, 336, 244-248.

3. Akalu S., Mengistou S., Leta S. 2011. Assessing Human Impacts on the Greater Akaki River, Ethiopia Using Macroinvertebrates, African Journals Online, 34(2).

4. Amrani A., El Wartiti M., Marini A., Zahraoui M., Naitza L. 2006. Analyse du dynamisme morphogénétique du bassin de la haute et moyenne Moulouya (Maroc) par couplage d'imagerie landsat et du modèle numérique de terrain Télédétection, 5(4), 379-391.

5. Arab A., Lek S., Lounaci A. \& Park Y.S. 2004. Spatial and temporal patterns of benthic invertebrate communities in an intermittent river (North Africa). Annales de Limnologie. International Journal of Limnology 40(4), 317-327. DOI: 10.1051/ $\operatorname{limn} / 2004029$.

6. Armitage P.D. 1995. Faunal community change in response to flow manipulation. In: Harper DM, Ferguson AJD, editors. The ecological basis for river management. Chichester: John Wiley \& Sons Ltd.; p. $59-78$ 
7. Augusto O. \& Marcos C. 2010. Benthic macroinvertebrates asbioindicators of water quality in an Atlantic forest fragment. Iheringia. Série Zoologia, Porto Alegre 100(4), 291-300.

8. Azrina M.Z., Yap C.K., Rahim I.A., Ismail A. \& Tan S.G. 2006. Anthropogenic impacts on the distribution and biodiversity of benthic macroinvertebrates and water quality of the Langat River, Peninsular Malaysia. Ecotoxicology and Environmental Safety 64(3), 337-347.

9. Bass D. 2003. A comparison of freshwater macroinvertebrate communities on small Caribbean islands. Bioscience. 53 (11), 1094-1100.

10. Bebba N., El Alami M., Arigue S. F., Arab A. 2015. Mesological and biotypological study of Mayflies populating in Abdi wadi (Algeria), J. Mater. Environ. Sci. 6(4), 1164-1177

11. Beneberu G., Mengistou S., Eggermont H., Verschuren D. 2014. Chironomid distribution along a pollution gradient in Ethiopian rivers, and their potential for biological water quality monitoring, African Journal of Aquatic Science, 39(1), 45-56

12. Bilton DT., Freeland JR., Okamura B. 2001. Dispersal in freshwater invertebrates. Annual Review of Ecology and Systematics. 32:159-181.

13. Cai Y., Xu H., Vilmi A., Tolonen K.T., Tang X., Qin B., Gong Z., Heino J. 2017a. Relative roles of spatial processes, natural factors and anthropogenic stressors in structuring a lake macroinvertebrate metacommunity. Science of Total Environment. 601-602, 1702-1711.

14. Cai Y., Gong Z., Qin B. 2012b. Benthic macroinvertebrate community structure in Lake Taihu, China: effects of trophic status, wind-induced disturbance and habitat complexity. J. Great Lakes Res. 38, 39-48. https://doi.org/10.1016/j.jglr.2011.12.009.

15. Cereghino R., Cugny P. \& Lavandier P. 2002. Infuence of intermittent hydropeaking on the longitudinal zonation patterns of benthic invertebrates in a mountain stream. International Review of Hydrobiology 87(1), 47-60.

16. Chahlaoui A. 1996. Etude Hydrobiologique de l'Oued Boufekrane - Impact sur l'environnement et la santé, Thèse d'état en Biologie. Univ. Moulay Ismail Fac. Sci. Meknès. p. 256.

17. Dudgeon D., Arthington A.H., Gessner M.O., Kawabata Z., Knowler D.J., Lévêque C., Naiman R.J., Prieur-Richard A.H., Soto D., Stiassny M.L., Sullivan C.A. 2006. Freshwater biodiversity: importance, threats, status and conservation challenges. Biol. Rev. 81, 163-182. https://doi.org/10.1017/ S1464793105006950.

18. El Agbani M.A. 1984. Le réseau hydrographique du bassin versant de l'oued Boureg reg (Plateau central Marocain), Essai de biotypologie. Thèse de 3 eme cycle. Écologie des eaux continentales. Uni. Claude
Bernard. Lyon I. p. 146.

19. El Haji M., Boutaleb S., Laamarti R., Laarej L. 2012. Qualité des eaux de surface et souterraine de la région de Taza (Maroc), bilan et situation des eaux, 8(1).

20. Fatoki OS., Lujiza N., Ogunfowokan AO. 2002. Trace metal pollution in umtata river, African Journals Online, 28(2).

21. Fekhaoui M., Dakki M., El agbani M. 1993. Faune benthique d'une revière polluée : l'oued sebou à l'aval de la ville de Fès (Maroc). Bull. Inst. Sci., Rabat, 17, 21-38.

22. Free G., Solimini A.G., Rossaro B., Marziali L., Giacchini R., Paracchini B., Ghiani M., Vaccaro S., Gawlik B.M., Fresner R., Santner G., Schönhuber M., Cardoso A.C. 2009. Modelling lake macroinvertebrate species in the shallowsublittoral: relative roles of habitat, lake morphology, aquatic chemistry and sediment composition. Hydrobiologia, 633, 123-136. https://doi.org/10.1007/ s10750-009-9869-7

23. Garrido J., Alaez M.F., Cueto J.A.R. 1994. Geographical distribution of adephaga and polyphaga (Coleoptera) in the Cantabrian mountains (Spain): specific richness and analysis of the altitude factor. Archiv für Hydrobiologie. 131:353-380.

24. Gasith A. and Resh V.H. 1999. Streams in Mediterranean Climate Regions: Abiotic Influences and Biotic Responses to Predictable Seasonal Events, Annual Review of Ecology and Systematics , 30, 51-81

25. Higler, L.W.G. 2009. Biology and Biodiversity of River Systems in J.C.I. Dooge (Ed.), Fresh Surface Water. Vol. Encyclopedia of Life Support Systems (EOLSS). II, pp. 222-231.

26. Karrouch1 L., Chahlaoui1 A., Essahale A. 2017. Impacts on the Distribution and Biodiversity of Benthic Macroinvertebrates and Water Quality of the Boufekrane River, Meknes, Morocco, Journal of Geoscience and Environment Protection, 5, 173-195.

27. Karrouch L. 2010. Bio-évaluation de la qualité des eaux courantes de la région Meknès (Centre- Sud, Maroc) - Impact sur l'environnement et la sante. Thèse doctorat es sciences en biologie. Faculté des sciences. Meknès, p. 216.

28. Lenat DR, Resh VH. 2001. Taxonomy and stream ecology - the benefits of genus- and species-level identifications. Journal of the North American Benthological Society. 20(2), 287-298.

29. Lencioni V., Rossaro B. 2005. Microdistribution of chironomids (Diptera: Chironomidae) in Alpine streams: an autoecological perspective. Hydrobiologia. 503, 61-76.

30. Mutlu E., Kurnaz A. 2017. Determination of 
seasonal variations of heavy metals and physicochemical parameters in sakiz pond (kastamonuturkey) Fresenius Environmental Bulletin, 26(4), 2807-2816.

31. Ripl W., Wolter K.D. 2005. The Lakes Handbook Volume 2: Lake Restoration and Rehabilitation. Blackwell Publishing, USA.

32. Rodier J., Bazin C., Broutin J.P., Chambon P., Champsaur H., Rodier L. 1996. The Analysis of Water. 8th ed. Dunod: Paris.

33. Rodusky A. J., Maki R.P., Sharfstein B. 2008. Back-pumping of agricultural runoff into a large shallow lake and concurrent changes in the macroinvertebrate assemblage, Water Research, 42(6-7), 1489-1500.

34. Sellam N., Zouggaghe F., Pinel Alloul B., Mimouni A., Moulaï R. 2017. Taxa richness and community structure of macroinvertebrates in rivers of different bioclimatic regions of Algeria, Journal of Materials and Environmental Sciences, 8(5), 1574-1588.

35. Smith V.H., Joye S.B., Howarth R.W. 2006. Eutrophication of freshwater and marine ecosystems. Limnol. Oceanogr. 51, 351-355. https://doi. org/10.4319/1o.2006.51.1_part_2.0351.

36. Tachet H.,Richoux P., Bournaud M. 2006. UsseglioPolatera P2006: Invertebres d'eau douce: systematique, biologie, ecologie. CNRS 2eme Editions, Paris, p. 588.

37. Tachet H., Richoux P., Bournaud M. \& UsseglioPolatera P. 2010. Freshwater invertebrates Systematics, biology, ecology. CNRS Ed., Paris 607p. (In French).

38. Tenkiano N S.D. 2017. Benthic macroinvertebrates and aquatic hyphomycetes: diversity and implication in the ecosystemic functioning of Guinean rivers. Université de Toulouse 3 Paul Sabatier (UT3 Paul Sabatier) (French)

39. Touron-Poncet H., Bernadet C., Compin A., Bargier N. \& Cereghino R. 2014. Implementing the Water Framework Directive in overseas Europe: A multimetric macroinvertebrate index for river bioassessment in Caribbean islands 2014.

40. Tuffery G.,Vernaux J. 1967. Method de determination de la qualité biologique des eaux courantes Exploitation codifiée des inventaire de la faune de fand. Tra. Div. Quoal.Eaux P Pisci, C.T.G.R.E.F.23p. Univ. Paul Sabatier, Toulose, 196, p. 61.

41. Wu Y., Liu E., Yao S., ZhuY., Xia W. 2010. Recent heavy metal accumulation in Dongjiu and Xijiu lakes, East China. J. Paleolimnol. 43, 385-392. https://doi.org/10. 1007/s10933-009-9337-4.

42. Yan H., Wang Y., Sun Li. 2014. High resolution oxygen isotope and grayscale records of a medieval fossil giant clam (Tridacna gigas) in the South China Sea: physiological and paleoclimatic implications. Acta Oceanol. Sin. 33(8), 18-25, DOI: 10.1007/ s13131-014-0399-4.

43. Zhang Y., Broussard R., Ke W., Gong X. 2014. The evaluation of a Scatter/Gather interface for supporting distinct health information search tasks. Journal of the Association for Information Science \& Technology. 65, 1028-1041.

44. Zalaghi A., Lamchouri F., Toufik H. 2018. Environmental impact study of the uncontrolled public landfills, by the expression of the descriptors of the integrated management system, Quality-Safety-Environment: The case of public landfill of Taza city (Morocco). International Journal of Innovation and Applied Studies, 24(1), 130-146. 